\title{
Corn stalk integrity is improved by fungicide combinations containing carboxamide
}

\section{Integridade de colmo de milho é melhorada por combinações de fungicidas contendo carboxamida}

\author{
Marina Freitas e Silva ${ }^{1 *}$, Wender Santos Rezende ${ }^{2}$, Domingos da Costa Ferreira Júnior ${ }^{3}$, \\ Thays Vieira Bueno ${ }^{2}$, Flávia Bastos Agostinhơ ${ }^{4}$, Césio Humberto de Brito ${ }^{1}$
}

\author{
'Universidade Federal de Uberlândia/UFU, Instituto de Ciências Agrárias, Uberlândia, MG, Brasil \\ 2Universidade Federal de Viçosa/UFV, Viçosa, MG, Brasil \\ ${ }^{3}$ Universidade Estadual Paulista Júlio de Mesquita Filho/UNESP, Faculdade de Ciências Agrárias e Veterinárias, Jaboticabal, SP, Brasil \\ ${ }^{4}$ Lousiana State University, Louisiana, United States of America \\ *Corresponding author: marinafreitas.agro@hotmail.com \\ Received in July 25, 2018 and approved in September 19, 2018
}

\begin{abstract}
Conservation of vegetative organs, as leaves and stalks, is essential to achieve high maize production. The objective of this work was to evaluate the effects of leaf area maintenance due to fungicides spraying on stalk integrity, its chemical composition and grain yield. The experiment was conducted in Uberlândia - MG, during the second season of 2016. The experiment design was a randomized complete block with six replications and six treatments, representing combinations of fungicides belonging to carboxamide, strobilurin, triazole, and dithiocarbamate chemical groups, and the check treatment (without fungicides). The assessed traits were leaf green area, wet and dry stalk density, stalk breaking strength and height, stalk lignin and cellulose percentage, stalk dry matter, stalk lignin and cellulose content per hectare and grain yield. Treatments containing fungicides, especially the ones containing carboxamide, resulted in higher leaf green area and stalk density. Application of fungicides also increased stalk breaking strength and height; however, no effect was observed on stalk lignin and cellulose percentage. Grain yield, stalk dry matter production, and stalk lignin and cellulose contents per hectare were enhanced by fungicide application, with higher improvements in plants treated with carboxamide. Application of fungicides, mainly when combined with carboxamides, promotes higher maintenance of leaf green area, which leads to improved stalk integrity, higher grain yield, and higher straw production.
\end{abstract}

Index terms: Zea mays L.; foliar area; lignin and cellulose; straw.

\begin{abstract}
RESUMO
A conservação dos órgãos da planta, como folhas e colmo, é essencial para que a cultura do milho atinja altas produtividades. O objetivo deste trabalho foi avaliar a influência da manutenção da área foliar, decorrente do uso de fungicidas, na integridade e composição do colmo e na produtividade do milho. O experimento foi conduzido em Uberlândia - MG, durante a segunda safra de 2016. O delineamento experimental foi o de blocos casualizados com seis repetições e seis tratamentos, sendo uma testemunha e os demais compostos por combinações de fungicidas pertencentes aos grupos químicos carboxamida, estrobilurina, triazol e ditiocarbamato. Avaliaram-se porcentagem de área verde foliar, densidade de colmo úmido e seco, força e altura de quebramento de colmo, teor de lignina e de celulose no colmo, produtividade de grãos e de matéria seca de colmo e quantidade de lignina e de celulose por hectare. Os tratamentos com fungicida proporcionaram maior área foliar e densidade de colmo, principalmente aqueles com carboxamida. Os fungicidas também aumentaram a força necessária ao quebramento de colmo e a altura de quebramento, porém não influenciaram o teor de lignina e de celulose no colmo. A produtividade de grãos e de matéria de seca de colmo e a quantidade de lignina e de celulose no colmo por hectare foram incrementadas pela aplicação de fungicidas, principalmente nos tratamentos com carboxamida. Aplicações de combinações de fungicida incluindo carboxamida proporcionam maior manutenção de área foliar, maior integridade de colmo, maior produtividade de grãos e maior formação de palhada.
\end{abstract}

Termos de indexação: Zea mays L.; área foliar; lignina e celulose, palhada.

\section{INTRODUCTION}

High grain yield in corn production is associated with the environmental conditions under which the plant is cultivated. These conditions are important to plant development and to maintenance of plant components such as roots, leaves, and stalk.
Corn stalk is responsible for water and nutrients transport, for sustain reproductive organs and leaves, besides being a storage organ (Sangoi et al., 2001; Gomes et al., 2010). In contrast, leaves are the main organ responsible for energy assimilation, and reduction in its area limits photosynthesis; hence, reduces grain yield (Rezende et al., 2015). One of the most challenging 
issue with protection of foliar area in corn production is controlling foliar disease. For that matter, application of fungicides is one of the most used management method.

Among the common chemical groups of fungicides used in corn production are triazoles and strobilurins. Triazoles are demethylation inhibitors that bound to $14 \alpha$-demethylase (CYP51) and inhibit ergosterol biosynthesis, a component of fungi cellular membrane (Heusinkveld et al., 2013; Stewart; Perry; Evans, 2014; Xavier et al., 2015). In contrast, strobilurins are inhibitors of mitochondrial respiration that bound to cytochrome bc1, block electron transport chain, and stop ATP synthesis (Fernandéz-Ortuño et al., 2008). Besides these two chemical groups, dithiocarbamates have also been used in corn production, which work through chelation of ions responsible for enzyme activation and through inhibition of general metabolic processes of pathogens (Lai; Chen; Chen, 2016).

In addition to disease control, fungicide application may enhance stalk integrity through maintenance of foliar area (Alvim et al., 2011; Wise; Muller, 2011; Brito et al., 2013; Henriques et al., 2014). Plants with damaged photosynthetic foliar apparatus relocate its carbohydrates from stalk to grains to mitigate foliar energetic deficit, which affects stalk stability (Sangoi et al., 2001). In this condition, stalk becomes more susceptible to breaking which impair mechanical harvest and reduce crop yield (Sangoi et al., 2001; Alvim et al., 2011).

Physiological and biochemical benefits were also reported in plants applied with different fungicides. Filippou et al. (2016) observed that kresoxim-methyl (strobilurin) application enhanced Medicago truncatula plants tolerance to water and saline stress. Moreover, Dal Cortivo et al. (2017) noticed that application of sedaxane fungicide (carboxamide) in corn seedlings result in similar effect to auxin and gibberellin phytohormones, as it stimulated, for example, the activity of glutamine synthetase enzyme.

Fungicides that belong to the chemical group carboxamide were recently release in the Brazilian market. It inhibits succinato desidrogenase (SDH) enzyme through bounding to ubiquinona receptors, which affect fungi metabolic respiration (Huang; Millar, 2013; Sierotzki; Scalliet, 2013). Because of its recent release, there is lack of study regarding the effect of this fungicide in corn production. This study was conducted to evaluate the effect of maintenance of foliar area through application of carboxamide, strobilurin, triazole and dithiocarbamate fungicides, on stalk integrity, stalk composition and grain yield in corn production.

\section{MATERIAL AND METHODS}

The experiment was conducted under second crop dry conditions, from February $17^{\text {th }}$ to July $6^{\text {th }}$ in 2016 at Floresta do Lobo farm, located in Uberlândia, MG (1905'35.75" S; $48^{\circ} 08^{\prime} 22.48^{\prime \prime} \mathrm{W}$; $953 \mathrm{~m}$ of altitude). The average annual temperature of the region is $22.8^{\circ} \mathrm{C}$, with $1493 \mathrm{~mm}$ of average annual rainfall, and clime classified as Aw according to Köppen classification. The soil in which the experiment was conducted is a Latosol RedYellow. The corn hybrid Supremo ${ }^{\circledR}$, which has a high yield potential, was used.

Corn seeds were mechanically sowed in a no-till system following soybean cultivation. Seeds were sowed $4 \mathrm{~cm}$ deep, with 0.6 and $0.3 \mathrm{~m}$ spacing between lines and plants, respectively, to achieve 72.000 plants ha ${ }^{-1}$. Along with sowing, fertilization with $250 \mathrm{~kg} \mathrm{ha}^{-1}$ of formulated NPK 8-20-20 was applied. Further fertilization was done with urea $(45 \%$ of $\mathrm{N})$ at $155 \mathrm{~kg} \mathrm{ha}^{-1}$. Each plot was composed by six $4.2 \mathrm{~m}$ lines, with a $0.8 \mathrm{~m}$ aisle separating the plots. The useful area of each plot was the four central lines, which totaled $10.08 \mathrm{~m}^{2}$.

The experimental treatments were composed by a control (without fungicide application) and five different combinations of fungicides (Table 1). There were three fungicide applications in each treatment that were carried out at $\mathrm{V}_{8}, \mathrm{~V}_{\mathrm{T}}$, and $\mathrm{R}_{2}$ stages. The commercial fungicides used were Opera ${ }^{\circledR}\left(133 \mathrm{~g} \mathrm{~L}^{-1}\right.$ pyraclostrobin $+50 \mathrm{~g} \mathrm{~L}^{-1}$ epoxiconazole), Orkestra ${ }^{\circledR}$ (333 g L $^{-1}$ pyraclostrobin + $167 \mathrm{~g} \mathrm{~L}^{-1}$ fluxapyroxad) and Unizeb Gold ${ }^{\circledR}\left(150 \mathrm{~g} \mathrm{~kg}^{-1}\right.$ mancozeb). All the fungicides used are registered for use in corn. In addition, all fungicide treatments were added with adjuvant in accordance to its manufacture's recommendations. The experiment was conducted in a randomized complete block design with six replications.

The treatments were applied using a $\mathrm{CO}_{2}$ pressurized back sprayer with $2 \mathrm{~L}$ of capacity, and six hydraulic tips which delivered an application volume of $150 \mathrm{~L} \mathrm{ha}^{-1}$. The usual crop management was performed to allow expression of the yield potential of the hybrid.

At $\mathrm{R}_{5}$ stage it was determined the percentage of foliar green area considering all plants of the plot, using a 0 to $100 \%$ scale. Before harvest, stalk breaking strength and breaking height as well as wet stalk density was measured. Stalk samples were collected to determine stalk dry density, stalk dry matter weight, stalk lignin and cellulose percentage, and stalk lignin and cellulose content per hectare. Harvest was done when grain moisture was $25 \%$. 
Table 1: Experimental treatments composed by different fungicides used in corn production.

\begin{tabular}{|c|c|c|c|c|}
\hline Treatments & Active ingredient & Chemical Group & Rate (g a.i. ha-1) & Application Time \\
\hline T1 & - & - & - & - \\
\hline $\mathrm{T} 2$ & $\begin{array}{l}\text { (pyraclostrobin + } \\
\text { epoxiconazole) * }\end{array}$ & (triazole + strobilurin) & $(99.75+37.5)$ & $\mathrm{V}_{8^{\prime}} \mathrm{V}_{\mathrm{T}}$ and $\mathrm{R}_{2}$ \\
\hline T3 & $\begin{array}{c}\text { (pyraclostrobin }+ \\
\text { epoxiconazole) }+ \\
\text { mancozeb }\end{array}$ & $\begin{array}{l}\text { (triazole }+ \text { strobilurin) }+ \\
\text { dithiocarbamate }\end{array}$ & $(99.75+37.5)+1500$ & $\mathrm{~V}_{8^{\prime}}, \mathrm{V}_{\mathrm{T}}$ and $\mathrm{R}_{2}$ \\
\hline \multirow{2}{*}{ T4 } & $\begin{array}{l}\text { (pyraclostrobin + } \\
\text { epoxiconazole) }\end{array}$ & (triazole + strobilurin) & $(99.75+37.5)$ & $\mathrm{V}_{8} * *$ \\
\hline & $\begin{array}{l}\text { (pyraclostrobin + } \\
\text { fluxapyroxad) }\end{array}$ & (strobilurin + carboxamide) & $(109.9+55.1)$ & $\mathrm{V}_{\mathrm{T}}$ and $\mathrm{R}_{2}$ \\
\hline \multirow[t]{2}{*}{ T5 } & $\begin{array}{c}\text { (pyraclostrobin }+ \\
\text { epoxiconazole) }+ \\
\text { mancozeb }\end{array}$ & $\begin{array}{l}\text { (triazole }+ \text { strobilurin })+ \\
\text { dithiocarbamate }\end{array}$ & $(99.75+37.5)+1500$ & $\mathrm{~V}_{8}$ \\
\hline & $\begin{array}{l}\text { (pyraclostrobin }+ \\
\text { fluxapyroxad) }\end{array}$ & (strobilurin + carboxamide) & $(109.9+55.1)$ & $\mathrm{V}_{\mathrm{T}}$ and $\mathrm{R}_{2}$ \\
\hline T6 & $\begin{array}{c}\text { (pyraclostrobin + } \\
\text { fluxapyroxad) }\end{array}$ & (strobilurin + carboxamide) & $(109.9+55.1)$ & $\mathrm{V}_{8^{\prime}} \mathrm{V}_{\mathrm{T}}$ and $\mathrm{R}_{2}$ \\
\hline
\end{tabular}

${ }^{*}$ :Active ingredients grouped into parentheses were commercial products composed by ready mixtures of these ingredients. $\mathrm{V}_{8}$ : vegetative stage of corn plants in which is observed eight fully expanded leaves; $\mathrm{V}_{\mathrm{T}}$ : tassel stage; $\mathrm{R}_{2}$ : reproductive stage of corn plants with grains classified as "water bubble". ${ }^{* *}$ : In $\mathrm{T}_{4}$ and $\mathrm{T}_{5}$ treatments, the combination of fungicides used in the first application $\left(V_{8}\right)$ was different of the other applications $\left(V_{T}\right.$ and $\left.R_{2}\right)$.

One line of the useful area of the plot was assigned to stalk density (wet and dry stalk) determination and stalk dry matter weight, whereas the other line was assigned to stalk breaking strength and breaking height. The first and last plant of these lines were not accounted in the measured variables.

Twenty sequential plants from one line in the useful area were cut at the first internode above ground for stalk dry matter and density determination. Ten plants were used to measure stalk dry matter and the other ten for stalk density (wet and dry stalk). Stalk dry matter was determined considering the first tassel ramification as the stalk upper limit and the first internode above ground as the stalk lower limit. For that the plants were cut at these limits and the leaves were removed. Stalk weight was converted to $\mathrm{kg} \mathrm{ha}^{-1}$ considering population of plants equals to 72.000 plants ha $^{-1}$, which was the population used in this experiment.

In order to determine wet stalk density, a stubble containing three internodes was cut from the base of the 10 remaining plants. Plant stubble was weighed and its length and diameter (biggest and smallest) measured. Considering that corn stalk has ellipse form, base area, volume and wet stalk density, were determined as described by Alvim et al. (2011). Stubbles were placed inside a forced air circulation oven at $65{ }^{\circ} \mathrm{C}$ until constant weight (approximately 72 hours). Each stubble was weighed and measured again (diameter and length) to determine dry stalk density, as also followed by Alvim et al. (2011).

Ten sequential plants from one line of the useful plot area were used to evaluate stalk strength against breaking. For that an inclinometer containing a dynamometer was used. Perpendicular strength was applied with a rope, at the stalk first ear insertion until stalk breaking (Gomes et al., 2010). The recorded strength on dynamometer at breakage moment was considered the stalk strength against breaking. In the same plants, breaking height was determined and considered as stalk breaking height.

The same stubbles used for dry stalk density determination were used for stalk lignin and cellulose content. Stubbles were fragmented using a pruning shear, crushed in a commercial blender, and ground in knife mill. From the samples obtained after this process, lignin (\% of lignin) and acid detergent fibers (ADF), according to AOAC (1990), were determined. With stalk lignin percentage and ADF, stalk cellulose (\% cellulose) was also determined. For that the following formula was used: $\%$ cellulose $=$ ADF - $\%$ lignin. Stalk lignin and cellulose content (expressed in $\mathrm{kg} \mathrm{ha}^{-1}$ ) was also calculated, through multiplication between lignin and cellulose percentage, and stalk dry matter per hectare. 
The middle four lines of the plot was harvest manually at July $6^{\text {th }}$ in 2016. A stationary thresher was used to thresh the ears. Grain weight and moisture were determined in the field using a scale and a moisture equipment (Mini GAC Plus ${ }^{\circledR}$ model). Grain yield was determined from plot weights, converted to $\mathrm{kg} \mathrm{ha}^{-1}$ and corrected to $13 \%$ of moisture.

Experimental data were submitted to analysis of variance using F test and means grouped by Scott-Knott test. Both tests were performed at 0.05 level of significance using Sisvar statistical program (Ferreira, 2011).

\section{RESULTS AND DISCUSSION}

The main diseases found in the present experiment were maize white spot (pathogen complex formed by Pantoea ananatis, Phaeosphaeria maydis, Phyllosticta maydis and Phoma sorghina) and gray leaf spot (Cercospora zeae-maydis). Plants applied with treatment $\mathrm{T} 6[3 \mathrm{x}(\mathrm{C}+\mathrm{S})]$, composed by strobilurin plus carboxamide spraying, had the highest foliar green area (Table 2). The other treatments containing carboxamide fungicide, T4 $[(\mathrm{T}+\mathrm{S}) / 2 \mathrm{x}(\mathrm{C}+\mathrm{S})]$ and $\mathrm{T} 5[(\mathrm{~T}+\mathrm{S})+\mathrm{D} / 2 \mathrm{x}(\mathrm{C}+\mathrm{S})]$, also resulted in higher foliar green area than the remaining treatments.

Application of fungicide maintains corn green leaves and photosynthetically active for longer time, even after the physiological maturity of the plant. This effect might result from disease control or, in the case of some fungicides, from the physiological effect of the active ingredient, such as reduction on ethylene synthesis or enhancement of nitrate reductase enzyme activity (Fargan et al., 2010). This effect is known as stay green and benefits conservation of water in plant organs which extends cellular turgor (Wise; Muller, 2011).
The treatment $\mathrm{T} 6[3 \mathrm{x}(\mathrm{C}+\mathrm{S})]$ resulted in higher wet stalk density, followed by $\mathrm{T} 4[(\mathrm{~T}+\mathrm{S}) / 2 \mathrm{x}(\mathrm{C}+\mathrm{S})]$ and $\mathrm{T} 5[(\mathrm{~T}+\mathrm{S})+\mathrm{D} / 2 \mathrm{x}(\mathrm{C}+\mathrm{S})]$. It is important to notice that those treatments were the only ones that contained carboxamide, and that $\mathrm{T} 6$ was the one that contained more applications of this chemical group (three applications). An increase in wet stalk density was also observed in plants applied with the other treatments (T2 and T3) compared to the control. Our results might be a consequence of higher leaf area maintenance due to fungicide spraying. Alvim et al. (2011) studying the effect of increasing levels of defoliation at $\mathrm{R}_{2}$ corn stage on stalk density and dryness observed that plants with lower photosynthetic apparatus increased stalk dryness. Moreover, these authors observed that defoliation higher than $20 \%$ reduced stalk density.

Reports in other crops, such as tomato and wheat, have shown a beneficial physiological effect of pyraclostrobin and fluxapyroxad, the same active ingredients used in the present study on treatments composed by strobilurin + carboxamide (Ramos et al., 2013; Smith et al., 2013). Thus, higher wet stalk density observed in treatments containing these active ingredients might be related to increased stomatal conductance promoted by the physiological effect of the fungicide, which increases water flow through the stalk. Araújo et al. (2011) observed higher photosynthetic rate in tomato (Solanum lycopersicum L.) mutants deficient in succinate dehydrogenase (SDH), the same enzyme inhibited by fungicides from carboxamide chemical groups. This result was related to higher stomatal conductance, mediated by higher organic acids concentrations from the Krebs cycle. Higher stomatal conductance resulted from carboxamide application was also observed by Ajigboye, Murchie and Ray (2014) in wheat production.

Table 2: Foliar green area percentage (FGA), wet stalk density (WSD), and dry stalk density (DSD) of corn plants treated with different fungicides, composed by triazole (T), strobilurin (S), dithiocarbamate (D), and carboxamide (C).

\begin{tabular}{cccc}
\hline Treatments & $\begin{array}{c}\text { FGA } \\
(\%)\end{array}$ & $\begin{array}{c}\text { WSD } \\
\left(\mathrm{g} \mathrm{dm}^{-3}\right)\end{array}$ & $\begin{array}{c}\text { DSD } \\
\left(\mathrm{g} \mathrm{dm}^{-3}\right)\end{array}$ \\
\hline T1- Control & $12.57 \mathrm{~d}$ & $340.87 \mathrm{~d}$ & $128.50 \mathrm{~b}$ \\
T2- $3 \times(\mathrm{T}+\mathrm{S})$ & $37.18 \mathrm{c}$ & $449.33 \mathrm{c}$ & $140.00 \mathrm{~b}$ \\
T3- 3x (T+S) + D & $49.88 \mathrm{c}$ & $476.17 \mathrm{c}$ & $147.83 \mathrm{a}$ \\
T4- (T+S) / 2x (S+C) & $62.73 \mathrm{~b}$ & $541.68 \mathrm{~b}$ & $162.00 \mathrm{a}$ \\
T5- (T+S) + D / 2x (S+C) & $63.57 \mathrm{~b}$ & $525.18 \mathrm{~b}$ & $153.17 \mathrm{a}$ \\
T6- 3x (S+C) & $74.96 \mathrm{a}$ & $599.32 \mathrm{a}$ & $161.50 \mathrm{a}$ \\
\hline
\end{tabular}

*Means followed by the same letter belong to the same group according to Scott-Knott test at 0.05 of significance. 
All plants applied with fungicides increased dry stalk density compared to the control, except for plants applied with $\mathrm{T} 2[3 \mathrm{x}(\mathrm{T}+\mathrm{S})]$. The lack of response observed in plants treated with $\mathrm{T} 2$ might be explained by its lack of control of maize white spot disease, the most expressed disease in corn foliar area (data non-shown); hence, the disease that most affected foliar area maintenance. Reports have shown that triazole plus strobilurin applications was not efficient in controlling maize white spot disease (Juliatti et al., 2014). However, when dithiocarbamate was added to this mixture, which is the present treatment $\mathrm{T} 3$ [ $3 \mathrm{x}$ $(\mathrm{T}+\mathrm{S})+\mathrm{D}$ ], plants presented higher dry stalk density than treatments containing triazole plus strobilurin only and the control. Bomfeti et al. (2007) observed that maize white spot disease was efficiently controlled by dithiocarbamate spraying, due to its bacteriostatic property on one of the disease agents, the bacterium Pantoea ananatis. As already mentioned, the other treatments containing dithiocarbamate, $\mathrm{T} 4[(\mathrm{~T}+\mathrm{S}) / 2 \mathrm{x}(\mathrm{C}+\mathrm{S})], \mathrm{T} 5[(\mathrm{~T}+\mathrm{S})+\mathrm{D} /$ $2 \mathrm{x}(\mathrm{C}+\mathrm{S})]$ and $\mathrm{T} 6[3 \mathrm{x}(\mathrm{C}+\mathrm{S})]$, also increased stalk density compared to the control. These results might be explained by the efficient effect of the treatments on maintenance of foliar area.

Treatments that required the highest strength to break corn stalk were T5 $[(\mathrm{T}+\mathrm{E})+\mathrm{D} / 2 \mathrm{x}(\mathrm{S}+\mathrm{C})]$ and T6 $[3 \mathrm{x}(\mathrm{S}+\mathrm{C})]($ Table 3$)$. The other treatments also required higher strength than the control. Healthy and dense stalks are stronger and resistant to breaking resulted from wind and rain factors (Magalhães; Durães; Oliveira, 1998; Alvim et al., 2011). As possible cause for stalk breaking, Blum et al. (2003) listed the redistribution of existing sugars from stalk to grains, and the stalk susceptibility to rot. Lower photosynthetic area resulted from foliar disease might promote this sugar redistribution to the grains (Sangoi et al., 2001; Rezende et al., 2015). Blum et al. (2003) reported that stalk rots are more frequent in plants with foliar diseases. Moreover, Alvim et al. (2011) observed that losses on active photosynthetic foliar area reduces stalk integrity and density, which enhanced plant susceptibility to breaking.

All treatments containing fungicides had taller stalk breaking point compared to the control, but no significant difference was observed among the fungicides treatments. Even broken corn plants can be mechanically harvested, depending on its breaking height (Alvim et al., 2011). Plants that break in a higher point benefit ear collection through mechanical harvest.

Gleason et al. (2011) noticed that lower activity of SDH affected hydrogen peroxide $\left(\mathrm{H}_{2} \mathrm{O}_{2}\right)$ production, which participates on lignin biosynthesis (Shafi et al., 2015). As carboxamides also affect SDH enzyme, it was studied if higher breaking resistance was related to lignification process. However, there was no treatment effect on stalk lignin percentage, as well as on stalk cellulose percentage (Table 3 ). Therefore, other than lignin biosynthesis, higher stalk integrity might be explained by higher stay green effect or higher production and maintenance of stalk dry matter (Table 4).

Table 3: Required strength for stalk breaking (RS), stalk breaking height $(\mathrm{BH})$, stalk lignin percentage (LIG) and stalk cellulose percentage (CEL) of corn plants treated with different fungicides, composed by triazole (T), strobilurin (S), dithiocarbamate (D), and carboxamide (C).

\begin{tabular}{ccccc}
\hline Treatments & $\begin{array}{c}\text { RS } \\
(\mathrm{kgf})\end{array}$ & $\begin{array}{c}\mathrm{BH} \\
(\mathrm{cm})\end{array}$ & $\begin{array}{c}\text { LIG } \\
(\%)\end{array}$ & $\begin{array}{c}\mathrm{CEL} \\
(\%)\end{array}$ \\
\hline T1- Control & 0.88 c & 26.40 b & 9.77 a & 46.41 a \\
T2- 3x (T+S) & 1.01 b & 34.05 a & 9.55 a & 44.83 a \\
T3- 3x (T+S) + D & 0.97 b & 34.42 a & 9.21 a & 43.82 a \\
T4- $(\mathrm{T}+\mathrm{S}) / 2 \times(\mathrm{S}+\mathrm{C})$ & 1.03 b & 38.03 a & 9.59 a & 43.25 a \\
T5- (T+S) + D / 2x (S+C) & 1.13 a & 36.01 a & 9.92 a & 43.12 a \\
T6- 3x (S+C) & 1.18 a & 36.44 a & 9.44 a & 43.13 a \\
\hline
\end{tabular}

*Means followed by the same letter belong to the same group according to Scott-Knott test at 0.05 of significance.

The highest stalk dry matter production per hectare was observed in plants that received treatments containing fungicides belonging to carboxamide chemical group, as well as the highest grain yield. These treatments (T4, T5 and T6) resulted in higher foliar tissue integrity, which increased production of photoassimilates that are used on stalk constitution and grain filling. Moreover, as already mentioned, treatments with higher foliar green area present enough photoassimilate production for grain filling and do not require redistribution from stalk storage to the grains. Therefore, there is higher stalk dry matter production and maintenance of the dry matter already produced in plants applied with these treatments.

As observed in our study, carboxamide application might also promote a positive physiological effect in plants. Fleitas, Gerard and Simón (2015) noticed increased grain yield and grain protein in wheat foliarly applied with fluxapyroxad, which was explained by a possible physiological benefit of carboxamide in the plant. Ajigboye, Murchie and Ray (2014) observed higher rates of $\mathrm{CO}_{2}$ assimilation and stomatal conductance in wheat treated with carboxamide. Moreover, Kandel et al. (2016) observed higher grain yield in soybean applied with fluxapyroxad, which were not related to disease control. 
Table 4: Stalk dry matter (SDM), grain yield (GY), lignin content (LC) and cellulose content (CC) per hectare in corn plants treated with different fungicides, composed by triazole (T), strobilurin (S), dithiocarbamate (D), and carboxamide (C).

\begin{tabular}{ccccc}
\hline Treatments & $\begin{array}{c}\text { SDM } \\
\left(\mathrm{kg} \mathrm{ha}^{-1}\right)\end{array}$ & $\begin{array}{c}\mathrm{GY} \\
\left(\mathrm{kg} \mathrm{ha}^{-1}\right)\end{array}$ & $\begin{array}{c}\text { LC } \\
\left(\mathrm{kg} \mathrm{ha}^{-1}\right)\end{array}$ & $\begin{array}{c}\text { CC } \\
\left(\mathrm{kg} \mathrm{ha}^{-1}\right)\end{array}$ \\
\hline T1- Control & $2255.45 \mathrm{~b}$ & $6026 \mathrm{c}$ & $220.62 \mathrm{~b}$ & $1043.59 \mathrm{~b}$ \\
T2- 3x (T+S) & $2376.31 \mathrm{~b}$ & $6682 \mathrm{~b}$ & $226.80 \mathrm{~b}$ & $1064.84 \mathrm{~b}$ \\
T3- 3x (T+S) + D & $2459.56 \mathrm{~b}$ & $6383 \mathrm{~b}$ & $226.55 \mathrm{~b}$ & $1077.58 \mathrm{~b}$ \\
T4- (T+S) / 2x (S+C) & $2568.65 \mathrm{a}$ & $7206 \mathrm{a}$ & $245.68 \mathrm{a}$ & $1104.36 \mathrm{~b}$ \\
T5- (T+S) + D / 2x (S+C) & $2624.61 \mathrm{a}$ & $7328 \mathrm{a}$ & $260.53 \mathrm{a}$ & $1131.65 \mathrm{a}$ \\
T6- 3x (S+C) & $2723.25 \mathrm{a}$ & $7591 \mathrm{a}$ & $256.96 \mathrm{a}$ & $1173.36 \mathrm{a}$ \\
\hline
\end{tabular}

${ }^{*}$ Means followed by the same letter belong to the same group according to Scott-Knott test at 0.05 of significance.

Even though no significant difference regarding lignin percentage was observed among the treatments, there was higher stalk lignin content per hectare in treatments containing carboxamide (T4, T5, and T6) (Table 4). This might have resulted from higher stalk dry matter production observed on these treatments, since lignin content was calculated through multiplication between lignin percentage and stalk dry matter. Lignin content directly affects the degradation speed of the plant residues in the soil (Meschede et al., 2012). Therefore, besides sanitary and physiological effects, it is suggested that carboxamide application increases straw production and longevity (lower degradation speed), which increases soil coverage and preservation; hence, increases agroecosystem sustainability (Siqueira-Neto et al., 2010).

In agreement to lignin content, $\mathrm{T} 5[(\mathrm{~T}+\mathrm{S})+\mathrm{D} /$ $2 \mathrm{x}(\mathrm{C}+\mathrm{S})]$ and $\mathrm{T} 6[3 \mathrm{x}(\mathrm{C}+\mathrm{S})]$ treatments also resulted in higher stalk cellulose content per hectare, even though no treatment effect was observed on stalk cellulose percentage. High cellulose production is important to bioenergy industries, especially because of the expansion of second generation bioethanol production, which has cellulose as the main substrate (Breitenbach et al., 2015).

\section{CONCLUSIONS}

Higher foliar green area promoted mainly by application of fungicide combinations containing carboxamide enhances stalk integrity (density, breaking strength, dry matter content, lignin and cellulose content per hectare) and grain yield of corn plants. Besides the sanitary and physiological effects that fungicide combination application promotes in corn plants, application of combined fungicides enhances straw production.

\section{REFERENCES}

AJIGBOYE, O. O.; MURCHIE, E.; RAY, R. V. Foliar application of isopyrazam and epoxiconazole improves photosystem II efficiency, biomass and yield in winter wheat. Pesticide Biochemistry and Physiology, 114(7):52-60, 2014.

ALVIM, K. R. T. et al. Redução da área foliar em plantas de milho na fase reprodutiva. Revista Ceres, 58(4):413-418, 2011.

AOAC - ASSOCIATION OF OFFICIAL ANALYTICAL CHEMISTS. Official methods of analysis. 15 ed. Washington: AOAC, 1990. 1298p.

ARAÚJO, W. L. et al. Antisense inhibition of the iron-sulphur subunit of cuccinate dehydrogenase enhances photosynthesis and growth in tomato via an organac acid-mediated effect on stomatal aperture. The Plant Cell, 23(2):620-627, 2011.

BLUM, L. E. B. et al. Desfolha, população de plantas e precocidade do milho afetam a incidência e a severidade de podridões de colmo. Ciência Rural, 33(5):805-812, 2003.

BOMFETI, C. A. et al. Avaliação de produtos químicos comerciais, in vitro e in vivo, no controle da doença foliar, mancha branca do milho, causada por Pantoea ananatis. Summa Phytopathologica, 33(1):63-67, 2007.

BREITENBACH, M. et al. Oxidative stress in fungi: Its function in signal transduction, interaction with plant hosts, and lignocellulose degradation. Biomolecules, 5(2):318-342, 2015.

BRITO, A. H. et al. Controle químico da cercosporiose, manchabranca e dos grãos-ardidos em milho. Revista Ceres, 60(5):629-635, 2013.

DAL CORTIVO, C. et al. Biostimulant effects of seed-applied sedaxane fungicide: Morphological and physiological changes in maize seedlings. Frontiers Plant Science, 8(1):1-11, 2017. 
FARGAN, E. B. et al. Efeito da aplicação de piraclostrobina na taxa fotossintética, respiração, atividade da enzima nitrato reductase e produtividade de grãos de soja. Bragantia, 69(4):771-777, 2010.

FERNANDÉZ-ORTUÑO, D. et al. Mechanisms of resistance to Qol fungicides in phytopathogenic fungi. International Microbiology, 11(1):1-9, 2008.

FERREIRA, D. F. Sisvar: A computer statistical analysis system. Ciência e Agrotecnologia, 35(6):1039-1042, 2011.

FILIPPOU, P. et al. Kresoxim-methyl primes Medicago truncatula plants against abiotic stress factors via altered reactive oxygen and nitrogen species signalling leading to downstream transcriptional and metabolic readjustment. Journal of Experimental Botany, 67(5):1259-1274, 2016.

FLEITAS, M. C.; GERARD, G. S.; SIMÓN, M. R. Eficacia de fungicidas sobre la roya de la hoja del trigo y su efecto sobre componentes del rendimiento y porcentaje de proteínas en grano. Revista FAVE - Ciências Agrárias, 14(2):1-16, 2015.

GLEASON, C. et al. Mitochondrial complex II has a key role in mitochondrial-derived reactive oxygen species influence on plant stress gene regulation and defense. Proceedings of the National Academy of Sciences of the United States of America, 108(26):10768-10773, 2011.

GOMES, L. S. et al. Resistência ao acamamento de plantas e ao quebramento do colmo em milho tropical. Pesquisa Agropecuária Brasileira, 45(2):140-145, 2010.

HENRIQUES, M. J. et al. Controle de helmintosporiose em milho pipoca com aplicação de fungicidas em diferentes épocas. Revista Ciências Exatas e da Terra e Ciências Agrárias, 9(2):45-57, 2014.

HEUSINKVELD, H. J. et al. Azole fungicides disturb intracellular $\mathrm{Ca}^{2+}$ in an additive manner in dopaminergic PC12 cells. Toxicological Sciences, 134(2):374-381, 2013.

HUANG, S.; MILLAR, A. H. Succinate dehydrogenase: The complex roles of a simple enzyme. Current Opinion in Plant Biology, 16(3):344-349, 2013.

JULIATTI, F. C. et al. Eficácia da associação de fungicidas e antibióticos no manejo da mancha branca do milho e seu efeito na produtividade. Bioscience Journal, 30(6):1622-1630, 2014.

KANDEL, Y. R. et al. Fungicides and cultivar effects on Sudden Death Syndrome and yield of soybean. Plant Disease, 100(7):13391350, 2016.

LAI, G.; CHEN, G.; CHEN, T. Speciation of As ${ }^{\prime \prime \prime}$ and $A s^{\vee}$ in fruit juices by dispersive liquid-liquid microextraction and hydride generation-atomic fluorescence spectrometry. Food Chemistry, 190(1):158-163, 2016.
MAGALHÃES, P. C.; DURÃES, F. O. M.; OLIVEIRA, A. C. Efeitos do quebramento do colmo no rendimento de grãos de milho. Ciência e Agrotecnologia, 22(3):279-289, 1998.

MESCHEDE, D. K. Teores de lignina e celulose em plantas de cana-de-açúcar em função da aplicação de maturadores. Planta Daninha, 30(1):121-127, 2012

RAMOS, A. R. P. et al. Fruit quality of tomato 'giuliana' treated with products with physiological effects. Semina: Ciências Agrárias, 34(6):3543-3552, 2013.

REZENDE, W. S. et al. Desenvolvimento e produtividade de grãos de milho submetido a níveis de desfolha. Pesquisa Agropecuária Brasileira, 50(3):203-209, 2015.

SANGOI, L. et al. Desempenho de híbridos de milho com ciclos contrastantes em função da desfolha e da população de plantas. Scientia Agricola, 58(2):271-276, 2001.

SHAFI, A. et al. Expression of SOD and APX genes positively regulates secondary cell wall biosynthesis and promotes plant growth and yield in Arabidopsis under salt stress. Plant Molecular Biology, 87(6):615-631, 2015.

SIEROTZKI, H.; SCALLIET, G. A. Review of current knowledge of resistance aspects for the next-generation succinate dehydrogenase inhibitor fungicides. Phytopathology, 103(9):880-887, 2013.

SIQUEIRA-NETO, M. et al. Soil carbon stocks under no-tillage mulch-based cropping systems in the Brazilian Cerrado: An on-farm synchronic assessment. Soil and Tillage Research, 110(1):187-195, 2010.

SMITH, J. et al. Quantifying the non-fungicidal effects of foliar applications of fluxapyroxad (Xemium) on stomatal conductance, water use efficiency and yield in winter wheat. Communications in Agricultural and Applied Biological Sciences, 78(3):523.535, 2013.

STEWART, T. M.; PERRY, A. J.; EVANS, M. J. Resistance of Zymoseptoria tritici to azoxystrobin and epoxiconzaloe in the lower North Island of New Zealand. New Zealand Plant Protection, 67(1):304-313, 2014.

WISE, K.; MUELLER, D. Are fungicides no longer just for fungi? an analysis of foliar fungicide use in corn. APSnet Features, 2011. Available in: <https://www. apsnet.org/publications/apsnetfeatures/Pages/ fungicide.aspx>. Access in: February, 28, 2018.

XAVIER, S. A. et al. Variação da sensibilidade de populações de Phakopsora pachyrhizi a fungicidas inibidores da desmetilação no Brasil. Summa Phytopathologica, 41(3):191-196, 2015. 